\title{
Influence of canopy and topographic position on soil moisture response to rainfall in a hilly catchment of Three Gorges Reservoir Area, China
}

\author{
LIU Muxing ${ }^{1,2}$, WANG Qiuyue ${ }^{1},{ }^{*}$ GUO Li ${ }^{2}$, YI Jun ${ }^{1}$, LIN Henry², ZHU Qing ${ }^{3}$, \\ FAN Bihang ${ }^{2}$, ZHANG Hailin ${ }^{1}$ \\ 1. College of Urban and Environmental Sciences, Central China Normal University, Wuhan 430079, China; \\ 2. Department of Ecosystem Science and Management, Pennsylvania State University, University Park, PA \\ 16802, USA; \\ 3. State Key Laboratory of Lake Science and Environment, Nanjing Institute of Geography and Limnology, CAS, \\ Nanjing 210008, China
}

\begin{abstract}
Rainfall provides essential water resource for vegetation growth and acts as driving force for hydrologic process, bedrock weathering and nutrient cycle in the steep hilly catchment. But the effects of rainfall features, vegetation types, topography, and also their interactions on soil water movement and soil moisture dynamics are inadequately quantified. During the coupled wet and dry periods of the year 2018 to 2019, time-series soil moisture was monitored with 5-min interval resolution in a hilly catchment of the Three Gorges Reservoir Area in China. Three hillslopes covered with evergreen forest (EG), secondary deciduous forest mixed with shrubs (SDFS) and deforested pasture (DP) were selected, and two monitoring sites with five detected depths were established at upslope and downslope position, respectively. Several parameters expressing soil moisture response to rainfall event were evaluated, including wetting depth, cumulative rainfall amount and lag time before initial response, maximum increase of soil water storage, and transform ratio of rainwater to soil water. The results indicated that rainfall amount is the dominant rainfall variable controlling soil moisture response to rainfall event. No soil moisture response occurred when rainfall amounts was $<8 \mathrm{~mm}$, and all the deepest monitoring sensors detected soil moisture increase when total rainfall amounts was $>30 \mathrm{~mm}$. In the wet period, the cumulative rainfall amount to trigger surface soil moisture response in EG-up site was significantly higher than in other five sites. However, no significant difference in cumulative rainfall amount to trigger soil moisture response was observed among all study sites in dry period. Vegetation canopy interception reduced the transform ratio of rainwater to soil water, with a higher reduction in vegetation growth period than in other period. Also, interception of vegetation canopy resulted in a larger
\end{abstract}

Received: 2019-09-20 Accepted: 2020-03-05

Foundation: National Natural Science Foundation of China, No.41771261, No.41601215; Hubei Province Natural Science Foundation of China, No.2015CFA141, No.2016CFA027, No.2019CFB766; Fundamental Research Funds for the Central Universities, No.CCNU18QN002, No.CCNU19TS001

Author: Liu Muxing (1979-), Professor, specialized in hydropedology and soil physics.

E-mail: liumuxing@mail. ccnu.edu.cn

"Corresponding author: Guo Li (1985-), PhD, E-mail: lug163@psu.edu 
accumulated rainfall amount and a longer lag time for initiating soil moisture response to rainfall. Generally, average cumulative rainfall amount for initiating soil moisture response during dry period of all sites $(3.5-5.6 \mathrm{~mm}$ ) were less than during wet period $(5.7-19.7 \mathrm{~mm})$. Forests captured more infiltration water compared with deforested pasture, showing the larger increments of both soil water storage for the whole soil profile and volumetric soil water content at $10 \mathrm{~cm}$ depth on two forest slopes. Topography dominated soil subsurface flow, proven by the evidences that less rainfall amount and less time was needed to trigger soil moisture response and also larger accumulated soil water storage increment in downslope site than in corresponding upslope site during heavy rainfall events.

Keywords: interception; infiltration; lateral flow; soil water storage; forest; pasture

\section{Introduction}

Soil moisture is addressed as a key variable controlling hydrologic process and vegetation growth in the critical zone of earth surface (Famiglietti et al., 1998; Brantley et al., 2017). The input and recharge balance of soil water influence the generation of runoff, soil erosion, landslide, debris flow and even the succession of ecosystem, especially in the mountainous area with thin soil layer, steep hillslope and humid climate (Sidle et al., 1995; McDonnell, 2003; Lin, 2010). Due to the important role of soil moisture to sustainable succession of hilly catchments, numerous studies focused on the temporal and spatial variations of soil moisture and related effecting factors (Wang et al., 2013; Jia and Shao, 2014; Zhu et al., 2014; Guo et al., 2018). Due to the complexity of rainfall process, vegetation, and local topography and their interactions, fully understanding the processes of soil moisture response to rainfall and soil water movement are still challenges and should be clarified more widely (Zhu et al., 2014; Guo et al., 2018).

Water balance and water movement of hilly catchments were mainly controlled by rainfall features, vegetation coverage, soil property, and topographic position (Zhou and Lin, 2008; Lana-Renault et al., 2014; Guo and Lin, 2018). Influence of rainfall features (e.g. amount, intensity, and duration) on infiltration process had been widely reported. Li et al. (2013) revealed that soil moisture of surface layers was extremely influenced by the amount of rainfall events in shrub-encroached grassland. Zhu et al. (2014) found soil moisture dynamics were significantly influenced by rainfall amount and rainfall intensity at top, upper, and middle positions in a humid hilly catchment, while they were mainly affected by lateral flow at the lower position. Also, Wang et al. (2013) indicated soil moisture was mainly replenished by 3-4 heavy rainfall events in summer.

Vegetation influenced soil moisture response to rainfall by canopy interception and evapotranspiration, which controlled the available rainwater amount for infiltration and output of soil water storage, respectively (Iida et al., 2005; Li et al., 2013). Canopy interception influenced soil moisture by decreasing rainfall contributed to infiltration, triggering stem flow, delaying rainfall process, and redistributing rainwater on soil surface (Crockford and Richardson, 2000). While the evapotranspiration process in forest or pasture coverage reduced soil water storage vastly (Wang et al., 2013; Guo and Lin, 2018). The function of interception and evapotranspiration varied with growth period of plant leaves, especially for deciduous forest and deforested pasture. Previous studies on soil moisture dynamic or water balance were concentrated in vegetation growth season, but seldom in fallow period (Tomer 
and Anderson, 1995; Wang et al., 2013; Jin et al., 2018). On considering the obvious differences in rainfall pattern, interception, and transpiration between winter and summer, the observation in the fallow period should be paid sufficient attention (Bales et al., 2011).

The importance of topographic position effects on soil moisture distribution was proposed by many researchers (Burt and Butcher, 1985; Hu and Si, 2014; Yu et al., 2018). Topography influenced soil hydraulic properties by altering the deposit of weathering soil materials, and triggering the occurrence of lateral flow by dominating the rainwater collecting area (Grayson et al., 1997; Lin and Zhou, 2008; Graham and Lin, 2011; Zhu et al., 2014; Guo et al., 2018). Topography is relative stable compared with seasonal changes of canopy, but the relation of soil moisture and terrain attributes are not stable. Western et al. (1999) demonstrated soil moisture pattern in a catchment of Australia exhibits a high degree of organization during wet period owing to surface and subsurface lateral flow according to topographic position, while less spatial organization existed during dry period. On the contrary, Bogena et al. (2010) found soil moisture had stronger correlation with terrain attributes in dry period than in wet period.

Soil hydraulic properties including porosity, permeability, and retention characteristics, which directly influence the transformation ratio of rainwater to soil water and water storage. Uchida et al. (2006) proposed that water retention characteristics and permeability of bedrock dominant soil moisture response to rainfall in steep and wet hillslopes with thin soil layers, while drainable porosity controlled water discharge when event rainfall amount up to $50 \mathrm{~mm}$. Famiglietti et al. (1998) examined spatial and temporal variability of $0-5 \mathrm{~cm}$ depth soil moisture along a hillslope transect, found topographic position jointed soil properties dominated redistribution of soil water, and porosity together with hydraulic conductivity strongly influenced surface moisture under wet condition, while relative elevation controlled soil moisture under dry conditions. Lin and Zhou (2008) indicated that occurrence of preferential flow at different topographic position varied with initial soil moisture and rainfall intensity. In short, soil moisture variation and its response to rainfall on hillslope were influenced by those interactions of the above variables instead of by one factor independently. As those research results varied with climates, vegetation, topography, and monitoring season, more works should be done in different regions.

Compared with abundant studies of soil moisture in Loess Plateau and arid-semiarid area of China (He et al., 2012; Wang et al., 2013; Hu and Si, 2014; Shao et al., 2016; Jin et al., 2018), limited study was conducted in humid region, especially in the upper and middle reaches of the Yangtze River (Xu et al., 2011). As the biggest hydropower project of the world, the Three Gorges Dam exerted a giant influence on hydrologic process, geologic activity, landscape, and even local climate (Wu et al., 2003). More geology hazards (e.g. landslide or debris flow) were triggered as the frequency of rainstorm increasing, and hillslope soil erosion and sediment in gorges reservoir were very serious (Yin et al., 2010; Sun et al., 2016). In the initial process of soil erosion and landslide, the features of soil moisture response to rainstorm events are susceptible and active, and related studies are needed for geologic disaster predict and control (Guzzetti et al., 2008). Although many studies focused on the relationship between rainfall intensity-duration control of landslides and debris flows, less attention was concentrated on soil moisture response to rainfall events on considering the differences in vegetation types and tomographic position and also their interactions. 
The objectives of this study were (1) to quantifying the independent and interacted effects of rainfall feature, vegetation type, and tomographic position on soil water dynamics and soil water infiltration processes and (2) to reveal the mechanism of rainfall, vegetation, and tomography effects on soil water movement.

\section{Materials and methods}

\subsection{Study area and monitoring sites}

This study area is located in a hilly catchment of Dalaoling National Forest Park $\left(30^{\circ} 00^{\prime} 13^{\prime \prime} \mathrm{N}-31^{\circ} 28^{\prime} 30^{\prime \prime} \mathrm{N}, 100^{\circ} 51^{\prime} 8^{\prime \prime} \mathrm{E}-111^{\circ} 39^{\prime} 30^{\prime \prime} \mathrm{E}\right)$, which belongs to the Three Gorges Reservoir Area and is located $40 \mathrm{~km}$ upstream of the Three Gorges Dam (Figure 1a). The area is characterized by acid crystalline bedrock in the Mesoproterozoic era and a subtropical monsoonal humid climate. According to the records of a meteorological station (200 m a.s.1.) from 1994 to 2014, the mean annual rainfall and evaporation are 1011 and $950 \mathrm{~mm}$, respectively; the mean annual air temperature is $16.7^{\circ} \mathrm{C}$, and the mean annual frost-free period is 283 days. Annual rainfall fluctuates between 1000 and $1340 \mathrm{~mm}$ with the majority occurring in July and August as summer storms, rainfall intensity beyond $48 \mathrm{~mm} / \mathrm{h}$ in July and August (Liu et al., 2018). A typical mountainous topography combined with steep slopes and deep valley dominates this region, with an elevation ranging from $200 \mathrm{~m}$ to $2008 \mathrm{~m}$. With the increasing elevation, the microclimate shows vertical changes, and the climate of the selected hilly catchment is cold, moist, and misty, and the relative humidity exceeds

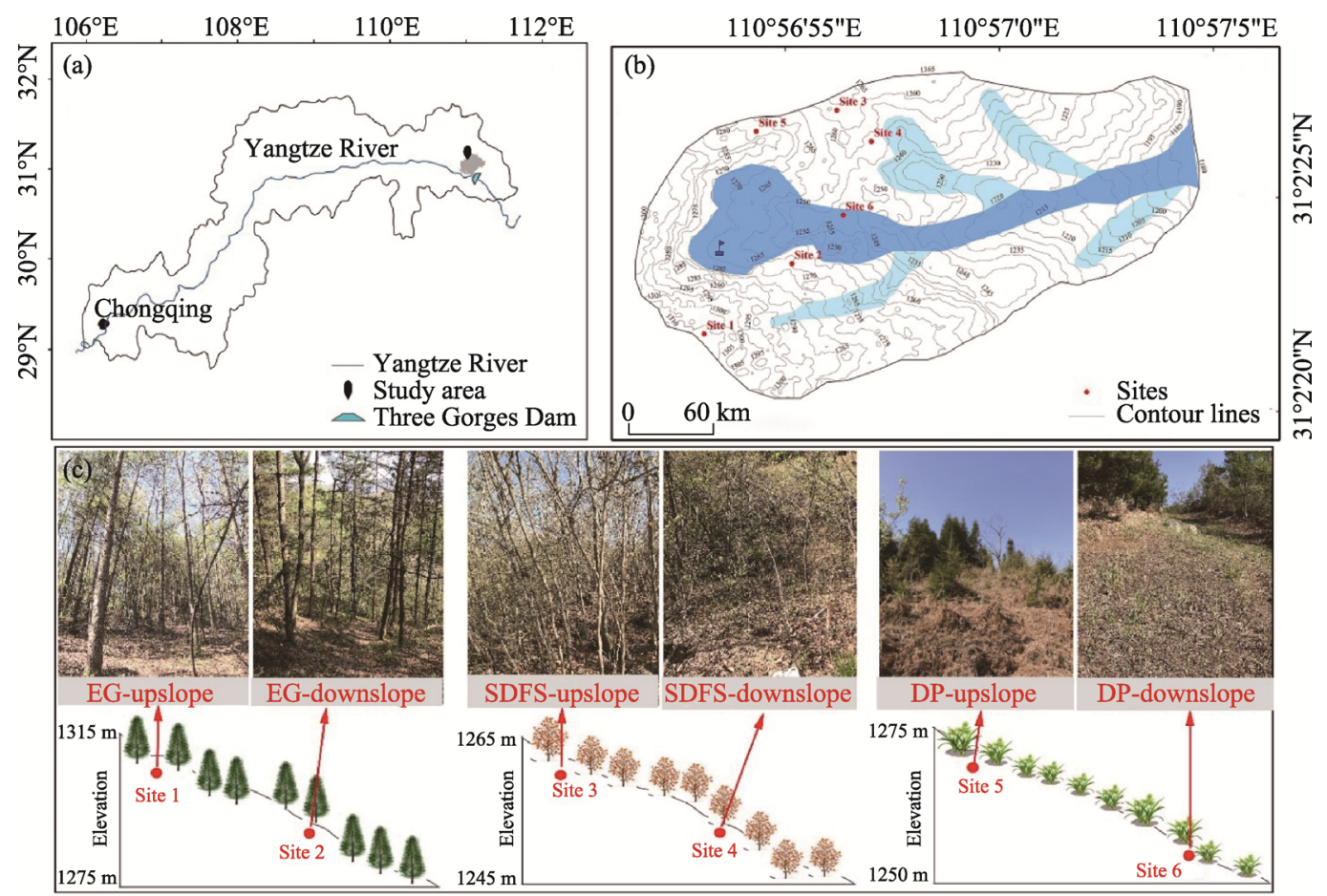

Figure 1 Three Gorges Reservoir Area (a) and study catchment (b), and the landscape of six monitoring sites (c) (EG, SDFS, and DP represent evergreen coniferous forest, secondary deciduous forest mixed with shrubs, and deforested pasture, respectively.) 
that of lower belts (Shen et al., 2001). The soil is classified as Boralfs according to the Soil Taxonomy (USDA, 1992). Excessive rainfall, intensive rainstorm, steep fractured terrain and easy erosive soil layer lead to serious soil erosion and flood hazard. Furthermore, after the destructive deforestation in the 1960s-1970s, large amount of original broad-leaved forest dominated by Castanopsis and Phoebe were destroyed, and were replaced by shallow-rooted coniferous forests or deciduous pastures, such as Cunninghamia lanceolata, Pinus massoniana, Cupressus funebris, and Pinus armandii, especially in the low-mountain areas, which aggravated soil erosion and sand deposition in reservoir. Fortunately, there still some temperate deciduous broad-leaved forest existing in the observed catchment, including Fagus engleriana, Liriodendron tulipifera, Castanea mollissima, Castanea henryi, and Pinus armandii (Shen et al., 2001).

\subsection{Soil moisture monitoring and soil property analysis}

Three hillslopes with typical vegetation cover and topography were selected in the studied catchment in the May of 2017, which were covered with evergreen coniferous forest (EG), secondary deciduous forest mixed with shrubs (SDFS), and deforested pasture (DP), respectively (Figures $1 \mathrm{~b}$ and $1 \mathrm{c}$ ). Two soil moisture monitoring sites were established on each hillslope, one in the upslope position and the other in the downslope position. The local slope gradients are $\sim 20^{\circ}$ and $\sim 29^{\circ}$ in EG, $\sim 27^{\circ}$ and $\sim 29^{\circ}$ in SDFS, and $\sim 25^{\circ}$ and $\sim 27^{\circ}$ in DP for the upslope and downslope position, respectively. The facing directions of EG, SDFS, and DP were Northeast, East, and Southeast, respectively. The altitudes of the upslope position and downslope position for EG, SDFS and DP were $1308 \mathrm{~m}$ and $1275 \mathrm{~m}, 1264 \mathrm{~m}$ and $1250 \mathrm{~m}$, and $1277 \mathrm{~m}$ and $1254 \mathrm{~m}$, respectively. At each site, a vertical array of soil integrated moisture-temperature probes (5TM probes with a typical accuracy of $\pm 2 \%$ without calibration, and a precision of \pm 0.08 vol.\% in moisture; METER Group, Inc. U.S.A) were installed in the upslope-facing direction in a soil pit at different depths. Installed depths of sensors were determined by the depths of different horizons (A, E, B, C...). Five sensors were installed at different depths from A horizon to the deepest $\mathrm{C}$ horizon in each site, and the detailed sensor depths were $10,20,35,50$, and $70 \mathrm{~cm}$ in site $1 ; 10,20,40,60$, and $80 \mathrm{~cm}$ in site $2 ; 8,20,30$, 45 , and $60 \mathrm{~cm}$ in site $3 ; 10,20,30,50$, and $70 \mathrm{~cm}$ in site $4 ; 10,20,30,45$, and $60 \mathrm{~cm}$ in site 5 ; and 10, 20, 40, 60, $80 \mathrm{~cm}$ in site 6 . In total, 30 sensors were installed in six monitoring sites of three vegetation coverage slopes (Table 1). Soil moisture and temperature data were recorded every $5 \mathrm{~min}$, and were stored in the EM50 data loggers (METER Group, Inc. U.S.A.). These measured data from May 1, 2018 to May 1, 2019 were used in this study.

A $1 \mathrm{~m}$ length with $1 \mathrm{~m}$ width plot was excavated at $2 \mathrm{~m}$ downslope of the soil monitoring sensor installed pit in each site. Soil structure and soil property, including soil layering, color, aggregate, soil texture, bulk density, porosity, and saturated hydrologic conductivity, were detected by field observation or laboratory analysis. Undisturbed soil cores $\left(100 \mathrm{~cm}^{3}\right)$ with ten replicates and about $500 \mathrm{~g}$ disturbed soil samples were collected at a $10 \mathrm{~cm}$ depth interval from soil surface down to the bedrock. These undisturbed soil samples were used for soil bulk density (oven drying method) and saturated hydraulic conductivity (constant pressure head method) measurement. These disturbed samples were prepared for particle size distribution analyze with the pipette method, and soil organic matter content were determined with the approach of oxidation with potassium dichromate (Walkley and Black, 1934). 
Table 1 Soil properties and sensor installation depths of six monitoring sites in the Three Gorges Reservoir Area

\begin{tabular}{|c|c|c|c|c|c|c|c|c|}
\hline \multirow{2}{*}{ Vegetation } & \multirow{2}{*}{$\begin{array}{l}\text { Location } \\
\text { (slope) }\end{array}$} & \multirow{2}{*}{$\begin{array}{l}\text { Sensor depth } \\
(\mathrm{cm})\end{array}$} & \multirow{2}{*}{$\begin{array}{c}\text { Soil } \\
\text { horizon }\end{array}$} & \multirow{2}{*}{$\begin{array}{l}\text { Soil bulk density } \\
\left(\mathrm{g} / \mathrm{cm}^{3}\right)\end{array}$} & \multicolumn{3}{|c|}{ Soil texture $(\%)$} & \multirow{2}{*}{$\begin{array}{l}\text { Soil organic matter } \\
\text { content }(\mathrm{g} / \mathrm{kg})\end{array}$} \\
\hline & & & & & Sand & Silt & Clay & \\
\hline \multirow{10}{*}{$\begin{array}{l}\text { Evergreen } \\
\text { coniferous } \\
\text { forest }\end{array}$} & \multirow{5}{*}{$\begin{array}{l}\text { Upslope } \\
\left(20^{\circ}\right)\end{array}$} & 10 & $\mathrm{Oe}$ & 0.71 & 50.41 & 32.97 & 16.63 & 57.0 \\
\hline & & 20 & A & 0.76 & 45.45 & 38.65 & 15.90 & 39.3 \\
\hline & & 35 & Bw1 & 1.01 & 47.03 & 39.78 & 13.19 & 28.4 \\
\hline & & 50 & $\mathrm{BC}$ & 1.3 & 56.78 & 19.45 & 23.77 & 23.8 \\
\hline & & 70 & $\mathrm{C}$ & 1.3 & 71.39 & 15.01 & 13.60 & 8.6 \\
\hline & \multirow{5}{*}{$\begin{array}{l}\text { Downslope } \\
\left(29^{\circ}\right)\end{array}$} & 10 & $\mathrm{Oe}$ & 0.66 & 40.85 & 35.26 & 23.89 & 37.0 \\
\hline & & 20 & A & 0.86 & 35.18 & 37.00 & 27.83 & 28.8 \\
\hline & & 40 & Bw1 & 0.91 & 33.72 & 38.64 & 27.63 & 11.6 \\
\hline & & 60 & Bw2 & 1.05 & 34.26 & 44.02 & 21.72 & 7.3 \\
\hline & & 80 & $\mathrm{C}$ & 1.32 & 61.14 & 24.67 & 14.18 & 4.1 \\
\hline \multirow{10}{*}{$\begin{array}{l}\text { Secondary } \\
\text { deciduous } \\
\text { forest } \\
\text { mixed } \\
\text { with shrub }\end{array}$} & \multirow{5}{*}{$\begin{array}{l}\text { Upslope } \\
\left(27^{\circ}\right)\end{array}$} & 8 & $\mathrm{Oe}$ & 1.08 & 27.68 & 48.51 & 23.82 & 46.6 \\
\hline & & 20 & A & 1.16 & 35.65 & 49.03 & 15.32 & 14.1 \\
\hline & & 30 & Bw1 & 0.99 & 66.28 & 23.40 & 10.32 & 8.4 \\
\hline & & 45 & Bw2 & 1.09 & 68.32 & 24.17 & 7.51 & 4.7 \\
\hline & & 60 & $\mathrm{C}$ & 1.26 & 70.92 & 10.40 & 18.68 & 4.8 \\
\hline & \multirow{5}{*}{$\begin{array}{l}\text { Downslope } \\
\left(29^{\circ}\right)\end{array}$} & 10 & $\mathrm{Oe}$ & 0.71 & 31.26 & 45.94 & 22.80 & 35.8 \\
\hline & & 20 & A & 0.77 & 27.26 & 48.69 & 24.05 & 31.0 \\
\hline & & 30 & Bw1 & 1.15 & 22.12 & 15.83 & 62.05 & 8.4 \\
\hline & & 50 & Bw2 & 1.42 & 37.16 & 10.38 & 52.46 & 5.9 \\
\hline & & 70 & $\mathrm{C}$ & 1.38 & 25.37 & 39.87 & 34.76 & 4.6 \\
\hline \multirow{10}{*}{$\begin{array}{l}\text { Secondary } \\
\text { deforested } \\
\text { pasture }\end{array}$} & \multirow{5}{*}{$\begin{array}{l}\text { Upslope } \\
\left(24.5^{\circ}\right)\end{array}$} & 10 & A & 0.78 & 52.57 & 24.26 & 23.17 & 38.7 \\
\hline & & 20 & Bw1 & 0.81 & 54.52 & 28.75 & 16.74 & 21.1 \\
\hline & & 30 & Bw2 & 0.93 & 56.47 & 24.93 & 18.60 & 19.8 \\
\hline & & 45 & $\mathrm{BC}$ & 1.05 & 55.02 & 24.68 & 20.29 & 5.1 \\
\hline & & 60 & $\mathrm{C}$ & 1.31 & 69.41 & 18.92 & 11.67 & 5.9 \\
\hline & \multirow{5}{*}{$\begin{array}{l}\text { Downslope } \\
\left(21.5^{\circ}\right)\end{array}$} & 10 & A & 0.78 & 30.27 & 41.95 & 27.78 & 32.2 \\
\hline & & 20 & $\mathrm{AB}$ & 0.93 & 26.76 & 45.48 & 27.77 & 25.9 \\
\hline & & 40 & Bw1 & 1.36 & 33.66 & 36.44 & 29.90 & 6.8 \\
\hline & & 60 & Bw2 & 1.39 & 35.42 & 28.93 & 35.65 & 4.6 \\
\hline & & 80 & Bw3 & 1.38 & 43.49 & 25.58 & 30.93 & 4.1 \\
\hline
\end{tabular}

Note: $\mathrm{O}, \mathrm{A}, \mathrm{B}$ and $\mathrm{C}$ represent organic horizon, eluvial horizon, illuvial horizon, and parent material horizon, respectively. $\mathrm{BC}$ represents the transition layer from $\mathrm{B}$ to $\mathrm{C}$.

\subsection{Precipitation measurement and event delineation}

An automatic tippling bucket rain gauge (Spectrum Technologies Inc, USA, precision \pm $0.2 \mathrm{~m}$ ) was installed in an uncovered area in the studied catchment, which was close to downslope deforested pasture (Figure 1). Precipitation of rainfall or snow melting was recorded every 5 min since May 1, 2018. As the rainfall occupied more than 95\% of precipitation during the monitoring period, the description of rainfall was used instead of precipita- 
tion for the following text. As the study area has a subtropical humid climate with longer rainfall duration, the continuous rainfall time series need to be separated into rainfall event for rainfall-soil moisture response. Previous studies have proposed several thresholds, such as minimum period without rain $\left(\mathrm{T}_{\mathrm{p}}\right)$ and minimum rainfall amount $\left(\mathrm{T}_{\mathrm{a}}\right)$, and determined that new rainfall events start when the period without rain exceeds $T_{p}$ and end when the rainfall amount is less than $\mathrm{T}_{\mathrm{a}}$. Considering the climates and study goals in this study, we defined $\mathrm{T}_{\mathrm{a}}$ as $1 \mathrm{~mm}$ and $\mathrm{T}_{\mathrm{p}}$ as $24 \mathrm{hr}$, as rainfall $<1 \mathrm{~mm}$ hardly trigger soil moisture change beyond $1 \%$ (the incidence of moisture response defined in section 2.4). Through this delineated approach, a total rainfall of $1235.3 \mathrm{~mm}$ during the monitoring period from May 1, 2018 to May 1, 2019 was divided into 55 events (E1 to E55 represent the 1 st to the 55th rainfall events) using for subsequent analysis of soil moisture response to rainfall events.

\subsection{Soil moisture response to rainfall event}

Different thresholds of the minimum increment of volumetric soil water content were used for determining the soil water response time of rainfall (Lin and Zhou, 2008; Graham and Lin, 2011; Zhu et al., 2014; Wiekenkamp et al., 2016; Jin et al., 2018). On considering the humid climate in the study area, $1 \%$ increment of cumulative soil moisture was defined as the minimum threshold for the soil response to rainfall event.

Parameters including wetting depth (indicated by the depth of the deepest probe that captured soil moisture response), soil moisture response time (the first appearance of an increase beyond $1 \%$ in soil moisture), infiltration velocity (dividing the depth by the response time), and maximum increment of soil moisture were calculated from the time series data of soil moisture during each rainfall event. These parameters were used to indicate the degree of soil water content response at a specific depth in different sites. Preferential flow occurred when subsurface horizon responded to rainfall earlier than horizons above it (Lin et al., 2008) and lateral flow refers to lateral flow indicated by sudden huge increase of soil water content to nearly saturated status (Guo et al., 2018).

Soil water storage (SWS, mm) of each soil profile was calculated by Equations (1), (2), and (3).

$$
\begin{aligned}
\mathrm{SWS}_{70 \mathrm{~cm}}= & \theta_{10 \mathrm{~cm}} \times 150 \mathrm{~mm}+\theta_{20 \mathrm{~cm}} \times 125 \mathrm{~mm}+\theta_{35 \mathrm{~cm}} \times 150 \mathrm{~mm}+\theta_{50 \mathrm{~cm}} \times \\
& 175 \mathrm{~mm}+\theta_{70 \mathrm{~cm}} \times 100 \mathrm{~mm} \\
\mathrm{SWS}_{80 \mathrm{~cm}}= & \theta_{10 \mathrm{~cm}} \times 150 \mathrm{~mm}+\theta_{20 \mathrm{~cm}} \times 150 \mathrm{~mm}+\theta_{40 \mathrm{~cm}} \times 200 \mathrm{~mm}+\theta_{60 \mathrm{~cm}} \times \\
& 200 \mathrm{~mm}+\theta_{80 \mathrm{~cm}} \times 100 \mathrm{~mm} \\
\mathrm{SWS}_{60 \mathrm{~cm}}= & \theta_{10 \mathrm{~cm}} \times 150 \mathrm{~mm}+\theta_{20 \mathrm{~cm}} \times 100 \mathrm{~mm}+\theta_{30 \mathrm{~cm}} \times 125 \mathrm{~mm}+\theta_{45 \mathrm{~cm}} \times \\
& 150 \mathrm{~mm}+\theta_{60 \mathrm{~cm}} \times 75 \mathrm{~mm}
\end{aligned}
$$

where $\theta$ is the volumetric soil water content $\left(\mathrm{cm}^{3} / \mathrm{cm}^{3}\right)$.

Transition of rainfall amount to soil water (RSP) during each rainfall event can be represented by ratio of the increment of soil water storage dividing accumulated rainfall amount.

\subsection{Statistical analysis}

Statistical analysis of soil moisture response features, including wetting depth, cumulative rainfall amount, lag time, maximum increment of soil water content, and SWS increase 
during 55 rainfall events were conducted. One-way ANOVA was used to test for differences in rainfall amount required to trigger all depths response rainfall events (AR), subsurface layer starting response events (SBR, deeper than $30 \mathrm{~cm}$ depth), and surface response events (SR, $10 \mathrm{~cm}$ soil depth). Statistical software SPSS 22.0 was used for the above analysis.

\section{Results}

\subsection{Category of rainfall events and dynamics of soil moisture}

The total rainfall amount during this period accumulated to $1235.3 \mathrm{~mm}$, and 55 rainfall events were separated by an interval of $24 \mathrm{hr}$ without rainfall, including 17 extremely light events with total amount $<5 \mathrm{~mm}, 9$ small rain events with total amount of 5-10 mm, 14 moderate rain events with total amount $10-25 \mathrm{~mm}, 10$ heavy rain events with total amount 25-50 mm, 3 heavy rain events with total amount 50-100 mm, and 2 storms with 24 hours amount $>100 \mathrm{~mm}$. The study period can be separated into two stages referring to the differences in rainfall amount and soil moisture response feature, including a wet period from May 1, 2018 to mid-November, 2018 and a dry period from mid-November, 2018 to May 1, 2019 (Figures $2 \mathrm{a}$ and $2 \mathrm{~b}$ ). The wet period and dry period are also corresponded to the growing and fallow season of DF. Due to the high correlations between total rainfall amount and other rainfall parameters, it was selected to categorize rainfall events in the subsequent soil moisture response analysis.

Time series of soil moisture with 30-minute interval showed that different patterns of soil moisture variation among five soil depths in six monitoring sites (Figures $2 \mathrm{c}-2 \mathrm{~h}$ ). The larger soil moisture variations among five depths were observed in EG-down, DP-down, and SDFS-up sites than in other three sites. Compared with corresponding upslope sites, the downslope sites of EG and DP were much wetter. While no distinct differences existed between the two sites in SDFS. Furthermore, the fluctuation of soil moisture was more distinct and frequent in wet period than in dry period for all monitoring sites. Except the DP-down site, surface soil horizons including $10 \mathrm{~cm}$ and $20 \mathrm{~cm}$ depth in other sites were more sensitive to rainfall than that of subsurface layers. Although the rainfall amount in wet period was significantly larger than in dry period, no obvious increase of soil water content was observed in wet period. And a 15-day period between June 3 and June 18 with little rainfall $(4.2 \mathrm{~mm})$ resulted in a sudden and steep decrease of soil moisture at the forest sites, especially at two EG sites.

\subsection{Soil moisture response to rainfall events and features of rainwater infiltration at different sites}

\subsubsection{Wetting depth during various rainfall events with influence of rainfall features}

The soil moisture responses were affected by the rainfall amount (Figure 3a). The soil moisture data showed that no soil moisture response occurred when the total rainfall amount was $<8 \mathrm{~mm}$. When rainfall amount was in the range of $8-15 \mathrm{~mm}$, the wetting front reached shallower surface layers of soil profile and mostly located at the depths from $8 \mathrm{~cm}$ to $20 \mathrm{~cm}$. As the rainfall amount increased to $>15 \mathrm{~mm}$, the response of soil moisture was observed at 
the soil layers lower than $30 \mathrm{~cm}$ depth. Until the rainfall amount was up to $30 \mathrm{~mm}$, all sensors detected soil moisture increment.
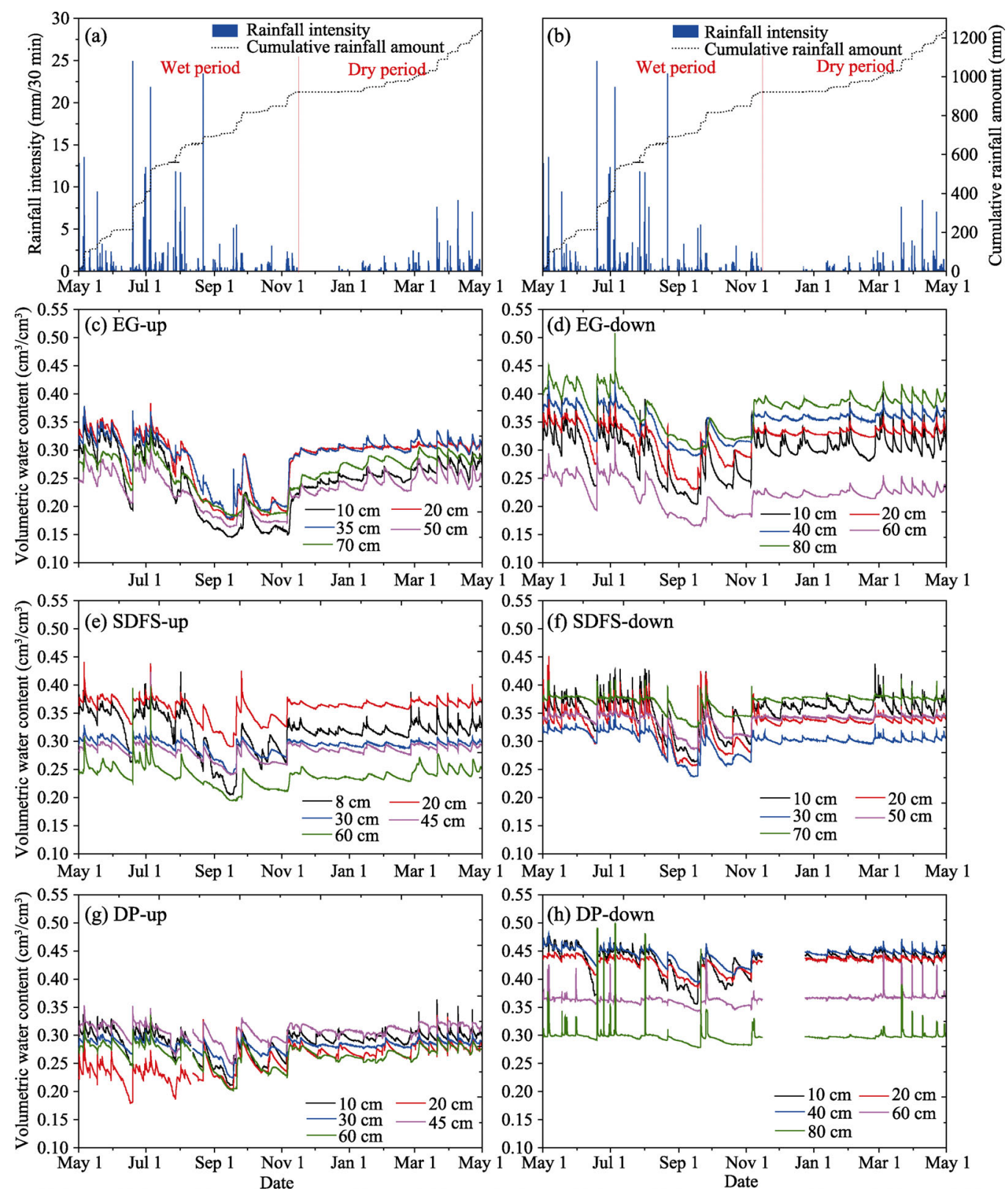

Figure 2 Rainfall distribution and dynamics (a-b) of soil moisture at different sites (c-h) from May 1, 2018 to May 1, 2019 of six monitoring sites in the Three Gorges Reservoir Area (EG, SDFS, and DP represent evergreen coniferous forest, secondary deciduous forest mixed with shrubs, and deforested pasture, respectively.)

Other features of rainfall events also had effects on soil wetting depths (Figures 3b-3d). Both rainfall duration (Figure 3b) and rainfall peak intensity (Figure 3d) of AR, SBR, SR and NR were significantly different $(\mathrm{P}<0.05)$, and were in the same order of $A R>S B R>$ $\mathrm{SR}>\mathrm{NR}$. The average rainfall intensity (Figure $3 \mathrm{c}$ ) of AR was significantly greater than that 
of NR, while there was no significant difference among AR, SBR, and SR or among SBR, $\mathrm{SR}$, and NR. In addition, the pattern of input rainfall led to different appearance of soil water infiltration wetting front. For example, the average rainfall of E44 (the 44th of rainfall event) is $21.4 \mathrm{~mm}$, however, the infiltration depth in EG during this rainfall event was less than 10 $\mathrm{cm}$ in upslope and $10 \mathrm{~cm}$ in downslope, respectively, which was significantly shallower than in the other rainfall events with similar rainfall amount.
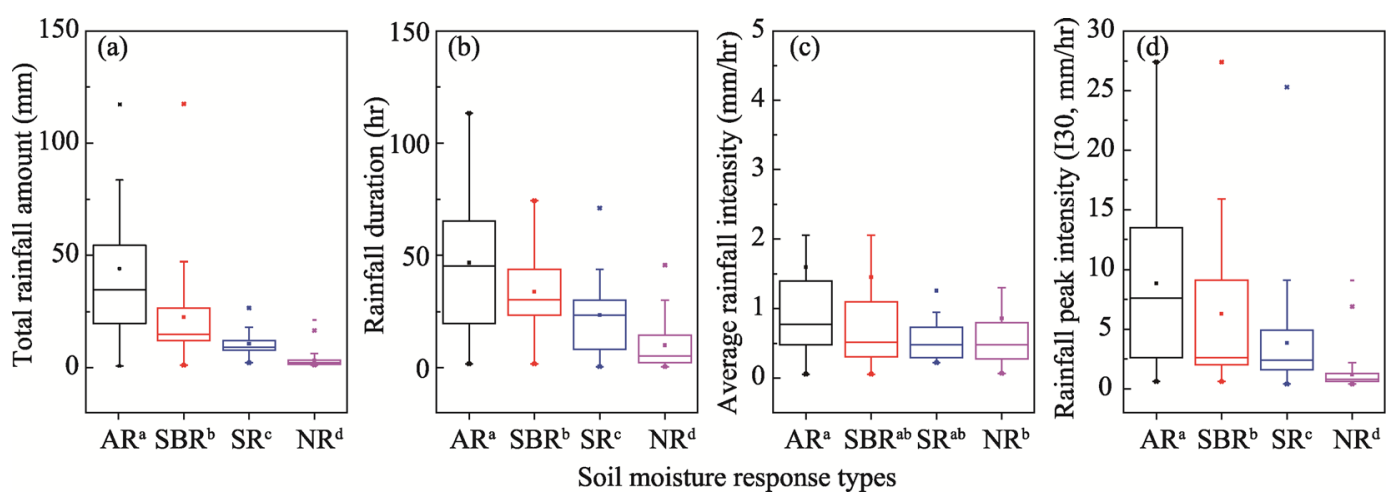

Figure 3 The effects of total rainfall amount (a), rainfall duration (b), average rainfall intensity (c), and rainfall peak intensity (d) on soil moisture responses of six monitoring sites in the Three Gorges Reservoir Area (AR refers to rainfall events with all the depths having response, SBR refers to rainfall events with subsurface layers starting response, SR refers to surface layer response to rainfall, NR refers to no response to rainfall. The alphabet “a, b, c, d, ab" refers to no significant difference at 0.05 level when up-mark containing same letters.)

3.2.2 Cumulative rainfall amount and lag time for triggering soil moisture response of surface horizon

In 23 out of 55 rainfall events, the topsoil $(0-10 \mathrm{~cm})$ of all sites had soil moisture response (Figure 4). Generally, average cumulative rainfall amount for initiating soil moisture response during dry period of all sites $(3.5-5.6 \mathrm{~mm})$ were less than during wet period $(5.7-19.7 \mathrm{~mm})$ (Figures $4 \mathrm{a}$ and $4 \mathrm{~b}$ ). In wet period, the rainfall amount for soil moisture response in EG-up was significantly higher than in other five sites, while no significant difference among the other five sites. In dry period, there was no significant difference in the cumulative rainfall for triggering soil moisture response among all the sites. Compared with the upslope sites and downslope sites in the same slope, cumulative rainfall amount needed for triggering moisture response of all upslope sites were larger than that of downslope sites. For the similar topographic position, the threshold of rainfall amount for soil moisture response in SDFS was higher than in DP and EG.

Differences in lag time for soil moisture response were also observed in different sites or during different rainfall periods. For the response lag time in wet period (Figure 4c), a longer time was observed in EG-up than in three downslope sites. While there was no significant difference in the lag time of all the sites in dry period (Figure 4d). For the similar vegetation coverage, the average lag time of soil moisture response in the topsoil of three upslope sites was greater than that of downslope sites. For the similar topographic position, the average lag time in EG sites were greater than in SDFS and DP. 

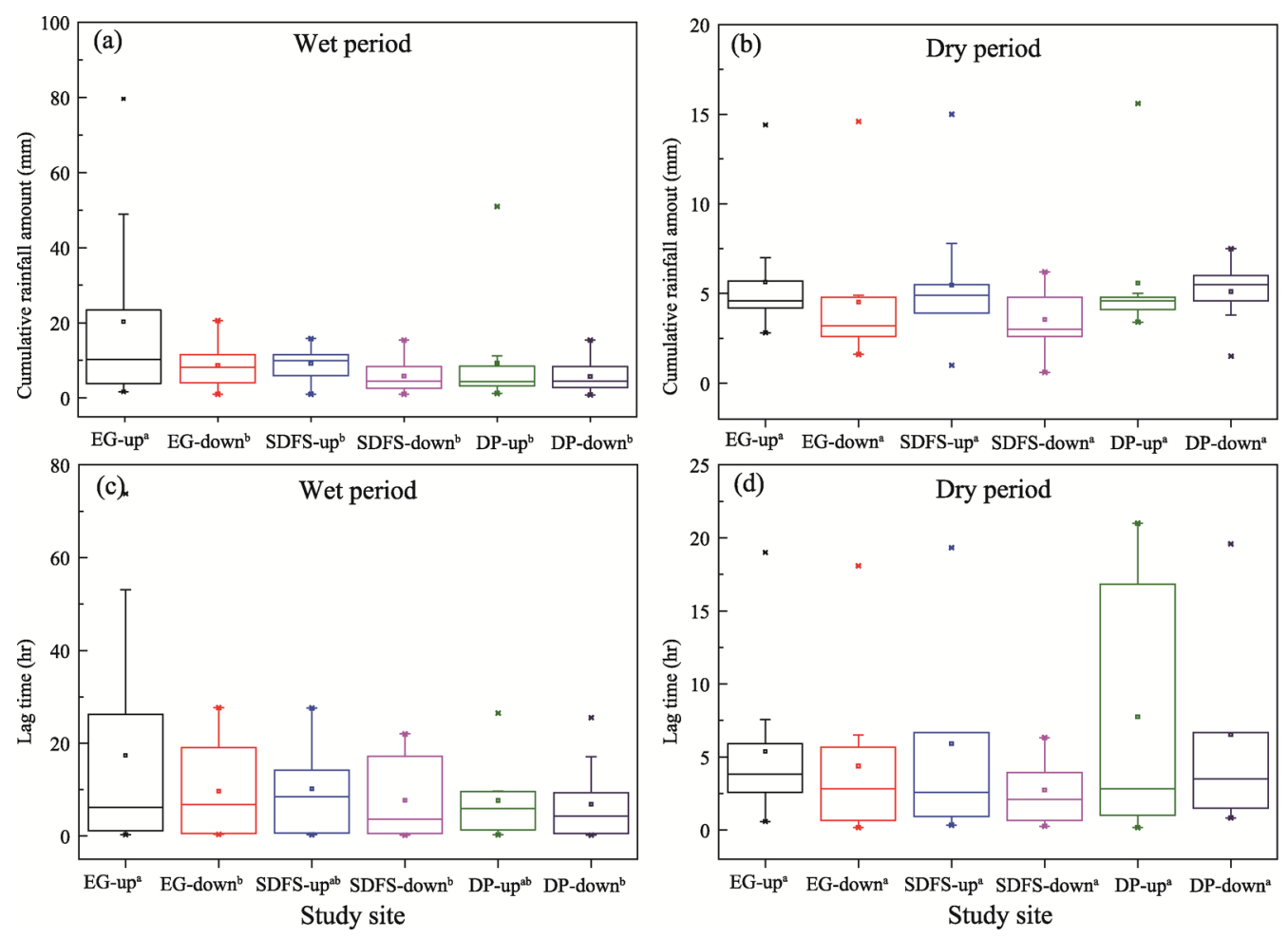

Figure 4 Cumulative rainfall amount and lag time for the initiation of soil moisture response at surface horizon in the Three Gorges Reservoir Area (EG, SDFS, and DP represent evergreen coniferous forest, secondary deciduous forest mixed with shrubs, and deforested pasture, respectively. The alphabet " $a, b$, ab" refers to no significant difference at 0.05 level when up-mark containing same letters.)

\subsubsection{Surface soil moisture response to four selected rainfall events}

Detailed information of cumulative rainfall amount and lag time for soil moisture response during four selected rainfall events (two in dry period and two in wet period) were shown in Figure 5. Four rainfall events were cataloged into different typical rainfall distribution patterns, including two events with continuing rainfall input but with larger intensity (E49) or lower intensity (E16) at the beginning, one event with lower intensity (E51), and one intermittent rainfall events with two individual subevents (E15). Both E49 and E51 occurred in the dry period, but the total rainfall amount and intensity of E49 was much larger than that of E51. The rainfall intensity of E16 was relatively small in the beginning and it increased with time, but the initial rainfall intensity of E49 was strong and the duration was long.

During two rainfall events in dry period, the cumulative rainfall amount required for the response of soil moisture in the surface soil $(8 \mathrm{~cm}$ or $10 \mathrm{~cm}$ depth) of rainfall with lower intensity was greater than that of heavy rain (Figure 5). The required cumulative rainfall amount of SDFS-down was the largest, and all the three upslope sites require larger rainfall amount than the downslope sites. However, during a rainfall event with both large rainfall amount and high rainfall intensity, the total rainfall amount required for the two SDFS sites to trigger soil moisture response were less than that of EG and DP. The surface soil moisture in three slopes at a same position responded to the rainfall simultaneously, while the cumulative rainfall amount required for EG-down site was smaller than the upslope site. For the 
rainfall events in wet period, the initial heavy rainfall intensity in E49 resulted in earlier soil moisture response than in E16, the surface soil moisture of all sites responded within 1 hour, and the upslope and downslope sites responded at the same time, respectively. The EG-down site was even earlier than the upslope site and the required cumulative rainfall was less than E16. During the E16 rainfall period, the SDFS downslope site responded earlier than other sites.
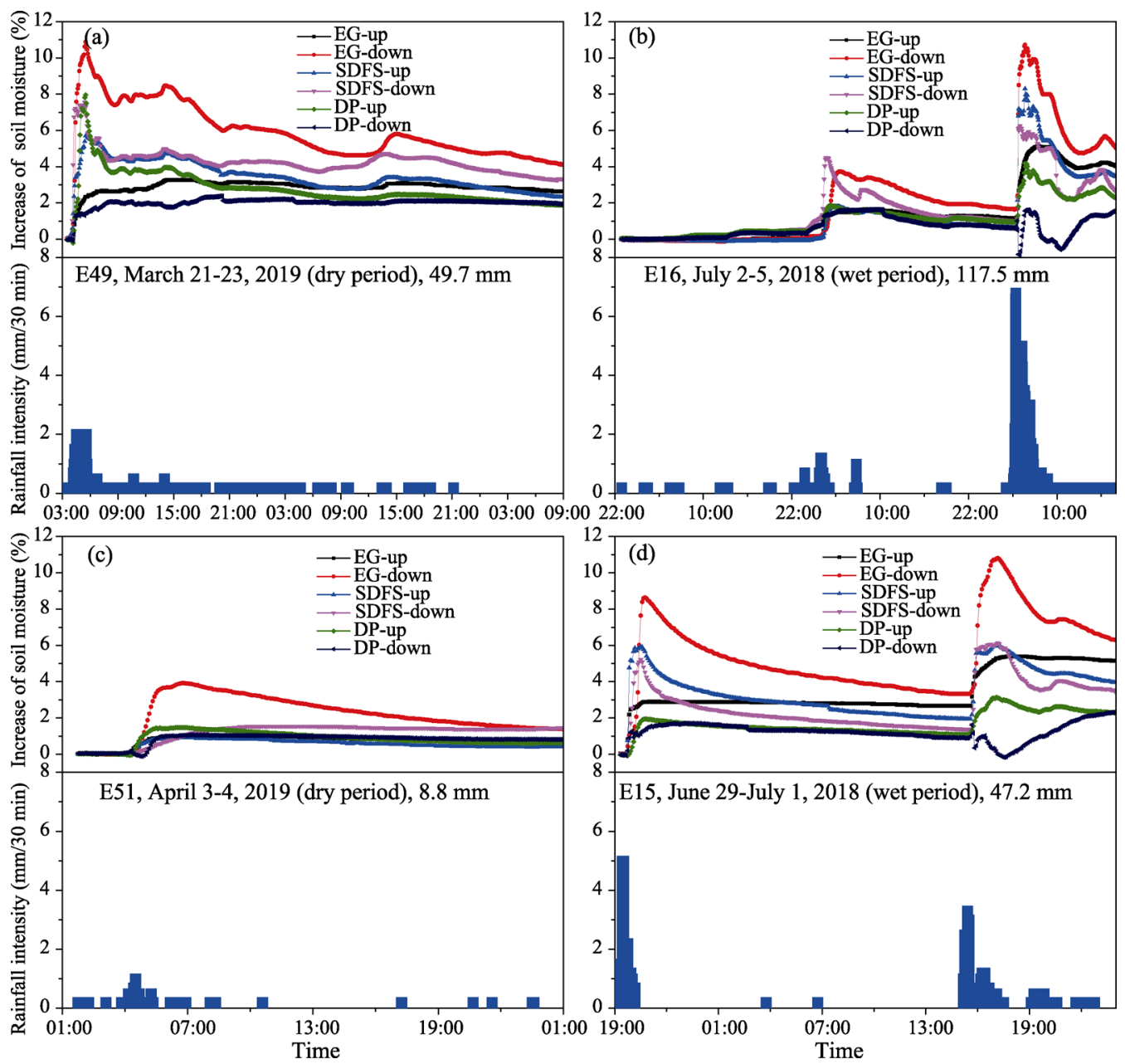

Figure 5 Rainfall distribution and dynamics of surface soil moisture during four selected rainfall events of six monitoring sites in the Three Gorges Reservoir Area (EG, SDFS, and DP represent evergreen coniferous forest, secondary deciduous forest mixed with shrubs, and deforested pasture, respectively.)

Different soil water response patterns were observed between E15 and E49 rainfall events, although their total rainfall amounts were close to each other. A faster soil moisture response speed was found in E15 than in E49, while more accumulated rainfall amount was needed in E15 for the $1 \%$ increment of soil moisture. Those upslope sites and downslope sites respond simultaneously in both forests, while the downslope site responded earlier than the upslope site in DP.

\subsubsection{Infiltration process during a heavy rainstorm event}

Soil moisture response time and soil water percolation velocity in the heavy rainstorm event of E11 were showed in Figure 6. All the depths of six monitoring sites responded to E11 in 4 
hrs. Also, preferential flow or lateral flow occurred for all the sites except for SDFS-down site. Vertical preferential flow appeared at the depths of $20-70 \mathrm{~cm}$ in EG-up site, $20 \mathrm{~cm}$ in SDFS-up site, $20 \mathrm{~cm}$ and $30 \mathrm{~cm}$ in SDFS-down site, $30 \mathrm{~cm}$ depth in DP-up site, and 20-40 $\mathrm{cm}$ in DP-down site. In addition, the lateral flow was proved by the evidence of large soil water increment in deep soil layer than its upper layer in both SDFS and DP sites.
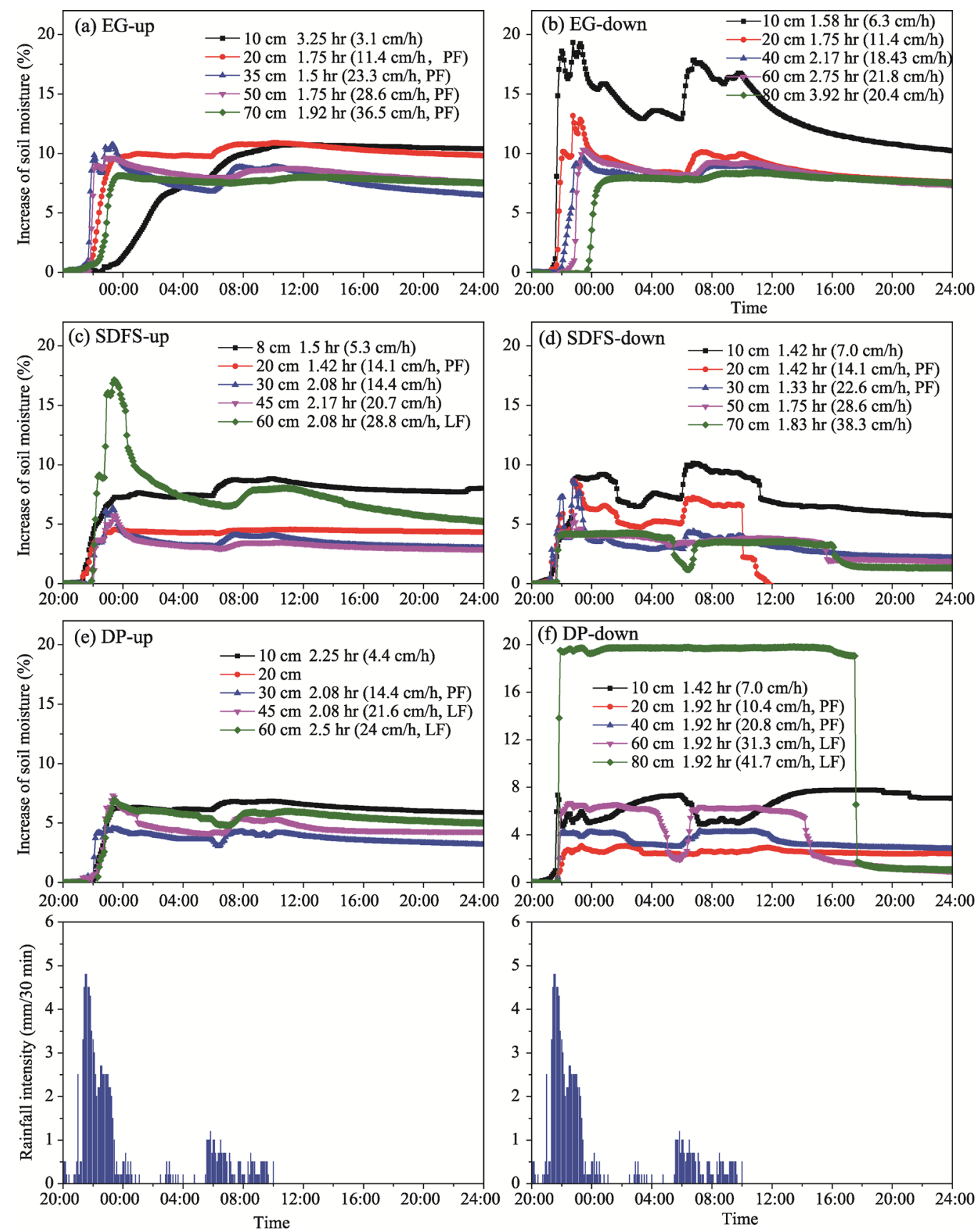

Figure 6 Infiltration process during a heavy rainstorm event of six monitoring sites in the Three Gorges Reservoir Area (EG, SDFS, and DP represent evergreen coniferous forest, secondary deciduous forest mixed with shrubs, and deforested pasture, respectively. The numbers besides depth legends presented lag time (hr) and average wetting-front velocity, respectively.) 
The preferential flow and lateral flow observed during E11 rainfall event presented in different soil moisture dynamics. In EG-up site, preferential flow at 20-70 cm depths led to an earlier soil moisture increase than at $10 \mathrm{~cm}$ soil depth. The lateral flow caused the large increments of soil moisture in $60 \mathrm{~cm}$ depth of SDFS-up site and $80 \mathrm{~cm}$ of DP-down site, and these increments were more than $17 \%$ and $20 \%$, respectively. However, the soil moisture changes between SDFS-up site and DP-down site were different after the soil water content reached a peak value, characterized by a steeply decrease in SDFS-up site and a continuously high soil moisture in DP-down site. Except for $80 \mathrm{~cm}$ soil depth in DP-down site, the soil moisture increments of other depths in DP slope were less than $8 \%$. However, the forest sites preserved more water than in DP sites, which was especially true for EG sites.

\subsection{Maximum increment of soil moisture and accumulated soil water storage in both dry period and wet period}

The maximum increase of soil moisture varied with rainfall amount and monitoring sites. The maximum increment of soil moisture at $10 \mathrm{~cm}$ soil depth was close to $20 \%$ in wet period (Figure 7a), while it was less than $12 \%$ in dry period (Figure 7b). Although 23 of the 55 rainfall events resulted in the increase of soil moisture at $10 \mathrm{~cm}$ soil depth, the magnitude of increment varied among different sites. During wet period, increase of soil moisture at EG-down site was significantly higher than in other five sites, and the soil moisture increase at SDFS-down was significantly higher than that of two sites in DP. During dry period, increase of soil moisture at EG-down site was significantly higher than those of EG-up, SDFS-up, and DP-down sites, while no significant difference existed among other sites.
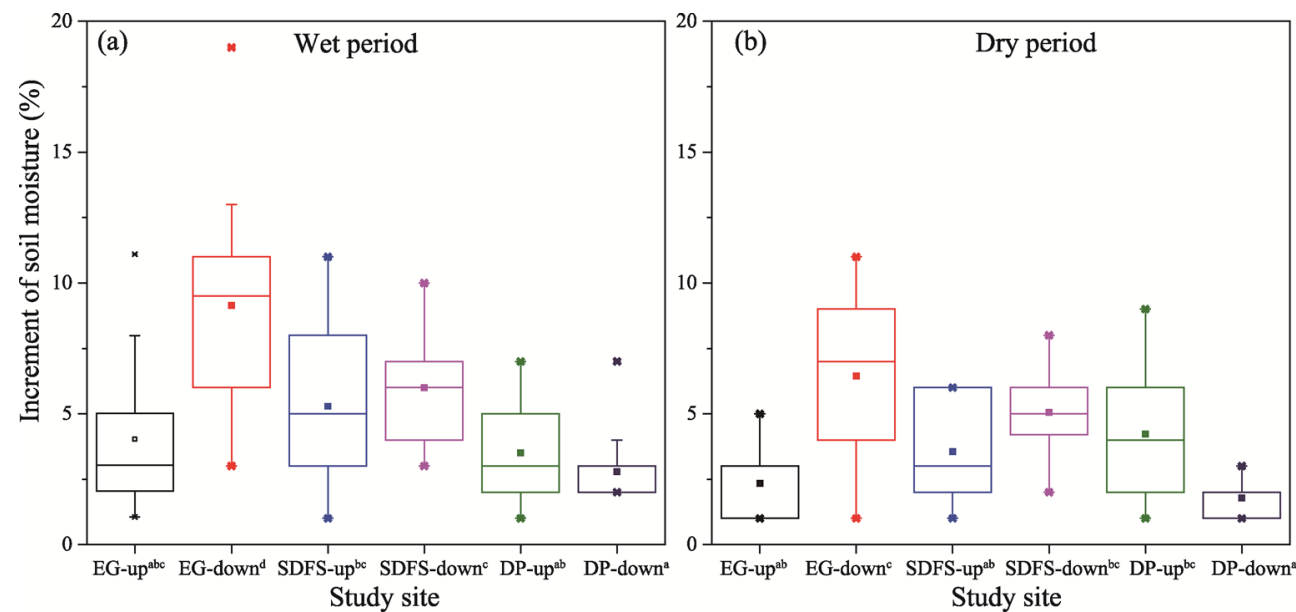

Figure 7 Maximum increase of soil water content for surface soil layer of six monitoring sites in the Three Gorges Reservoir Area, including 14 events in wet period (a) and 9 events in dry period (b) (EG, SDFS, and DP represent evergreen coniferous forest, secondary deciduous forest mixed with shrubs, and deforested pasture, respectively. The alphabet " $a, b, c, d, a b, b c, c d, b c d$ " refers to no significant difference at 0.05 level when up-mark containing same letters.)

The RSP varied with accumulated rainfall amount and study sites (Figure 8 ). The average values of RSP during dry period at EG-up (32.1\%), EG-down (47.5\%), SDFS-down (52.4\%), and DP-down (36.0\%) sites were larger than those during wet period $(31.8 \%-44.7 \%)$. While 
those of SDFS-up site (26.2\%) and DP-up site (24.4\%) during dry period was less than during wet period $(27.0 \%$ and $32.1 \%)$. Comparison of RSP at different sites during the same period, the highest value was observed in SDFS-down site and EG-down site during the wet period and during the dry period, respectively. While the DP-up site had the least RSP during both periods.
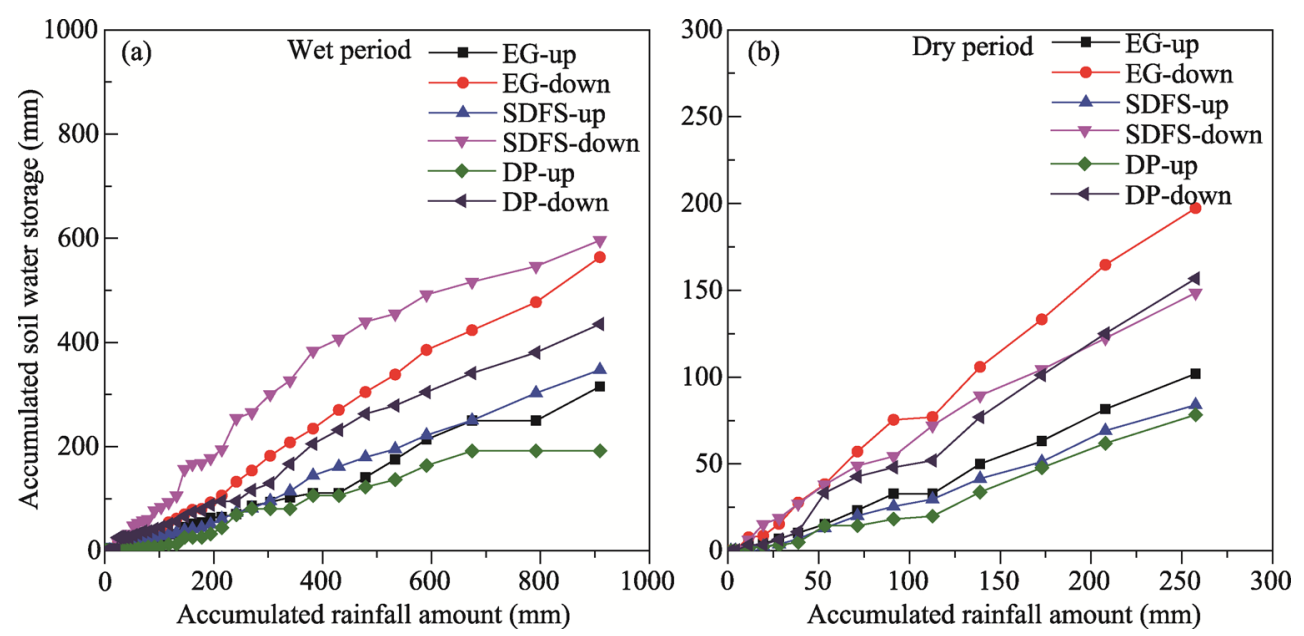

Figure 8 Accumulated soil water storage and accumulated rainfall amount at six monitoring sites during both wet period (a) and dry period (b) in the Three Gorges Reservoir Area (EG, SDFS, and DP represent evergreen coniferous forest, secondary deciduous forest mixed with shrubs, and deforested pasture, respectively.)

\section{Discussion}

Soil moisture response to rainfall event mostly related with two groups of variables, which included the first group of input rainfall features such as rainfall amount, rainfall duration, and rainfall intensity, and the second group of vegetation-topography-soil property combination governing the distribution and transition process from rainwater to soil water (Graham and Lin, 2011; Guo and Lin, 2018).

\subsection{Rainfall features influence on soil moisture dynamics and infiltration processes}

Among the first group variables, our studied results suggested that rainfall amount was the first order controlling factor on soil moisture respond process as it significantly influenced the wetting front depths (Figure 3), proven by the results that significant differences in the threshold of rainfall amount to trigger soil moisture response for whole profile, subsurface soil layer, and surface soil layer. Seldom soil moisture response occurred at six monitoring sites when the amount of rainfall event was $<8 \mathrm{~mm}$, implying that the slight rainfall event was unable to trigger soil moisture increment. Li et al. (2015) addressed a similar finding in Taihu Lake basin, which showed that small rainfall events have very little impact on the soil moisture in forestland. Jin et al. (2018) found $9 \mathrm{~mm}$ of accumulated rainfall amount was necessary to trigger soil moisture response at grassland and upslope of forest land, while 14 $\mathrm{mm}$ was required for the gully site of forestland based on the observations in Loess Plateau of China. The less rainfall amounts were needed for triggering soil moisture increase in this study than in above mentioned studies, implying the function of rainwater capture and de- 
posit were better in this study area.

The influence of rainfall on soil moisture was also proved by the significant correlation coefficients between rainfall features and maximum increment of soil water storage. Significant correlation between SWS increment and rainfall amount were observed in both wet period and dry period, especially during wet period with a coefficient larger than 0.8 (except for SDFS-down, which is $0.618, \mathrm{P}<0.01$ ). Although the soil moisture increment was also positively related with both rainfall duration and rain intensity in some period, the correlation coefficients were smaller than those with rainfall amount (Table 2). This result was consistent with the study conducted at Taihu basin (Zhu et al., 2014), which found that the degree of soil moisture change was more significantly influenced by rainfall amount than by rainfall intensity. Wiekenkamp et al. (2016) also addressed that rainfall amount was the dominated variable of rainfall features for controlling water infiltration process as it was most prominently correlated with occurrence frequency of preferential flow. The correlation coefficients difference between wet period and dry period was partly attributed to the different real regime of soil water potential when rainfall events started. Albertson and Kiely (2001) demonstrated that drainage processes determined the distribution of soil moisture in a wet regime, while water stress on transpiration affected soil moisture distribution in dry period.

Table 2 Correlation coefficients between maximum increment of soil water storage and rainfall features during both wet period and dry period of six monitoring sites in the Three Gorges Reservoir Area

\begin{tabular}{|c|c|c|c|c|c|c|}
\hline \multirow{2}{*}{ Site } & \multicolumn{3}{|c|}{ Wet period } & \multicolumn{3}{|c|}{ Dry period } \\
\hline & Intensity & Amount & Duration & Intensity & Amount & Duration \\
\hline EG-up & 0.226 & $0.937^{* *}$ & $0.509^{* *}$ & 0.519 & $0.896^{* *}$ & $0.536^{*}$ \\
\hline EG-down & $0.343^{*}$ & $0.922^{* *}$ & $0.489^{* *}$ & 0.490 & $0.879^{* *}$ & $0.550^{*}$ \\
\hline SDFS-up & 0.255 & $0.937^{* *}$ & $0.494^{* *}$ & 0.437 & $0.908^{* *}$ & $0.648^{*}$ \\
\hline SDFS-down & $0.500^{* *}$ & $0.618^{* *}$ & 0.289 & 0.400 & $0.911^{* *}$ & $0.607^{*}$ \\
\hline DP-up & $0.431^{*}$ & $0.875^{* *}$ & $0.514^{* *}$ & $0.564^{*}$ & $0.896^{* *}$ & 0.540 \\
\hline DP-down & $0.333^{*}$ & $0.822^{* *}$ & $0.414^{* *}$ & $0.565^{*}$ & $0.867^{* *}$ & 0.404 \\
\hline
\end{tabular}

Note: EG, SDFS, and DP represent evergreen coniferous forest, secondary deciduous forest mixed with shrubs, and deforested pasture, respectively; ${ }^{* *}$ indicates significant at $P<0.01,{ }^{*}$ indicates significant at $P<0.05$.

\subsection{Vegetation coverage influence on soil moisture response to rainfall event and soil water dynamics}

Influence of vegetation on the transition of rainwater to soil water or overland flow has been widely discussed (Gash et al., 1979; Brantley et al., 2017). Several evidences in this study indicated that vegetation play a critical role in regulating rainfall infiltrated into soil profile. Firstly, the time series soil moisture dynamics showed no apparent magnitude difference in soil moisture between vegetation growth period and fallow period, although the rainfall amount in wet period was $615.6 \mathrm{~mm}$ higher than in dry period. In addition, the 15 days with little rainfall in vegetation growth period led steep soil moisture decreases in the forest sites, while the soil moisture decrements in fallow period or in DP sites were more gently. These phenomena were related with much higher transpiration of forest canopy in summer. Secondly, a much higher rainfall amount of all sites was required to initiate soil moisture re- 
sponse in wet period $(5.7-19.7 \mathrm{~mm})$ than in dry period $(3.5-5.6 \mathrm{~mm})$, which was partly explained by a higher interception in vegetation growth season than in fallow season. This result was consistent with the observation from Jin et al. (2018), who found dense canopy of forestland required a higher rainfall amount to initiate soil moisture response than in other landscape. Thirdly, the difference in RSP between wet period and dry period also demonstrated the effects of vegetation on soil moisture response to rainfall events. The result showed the higher RSPs in SDFS-down site and EG-down site in wet period and in dry period, respectively, implying the vegetation types significantly affected rainfall water infiltration and soil water conservation. In addition, the lowest RSP occurred at DP-up site in both wet period and wet period, indicating a better soil water conservation capacity in the forests than in the deforested pasture.

\subsection{Topographic position influence on soil moisture dynamics and soil water move- ment}

Topography controls soil moisture response to rainfall events through direct influence on lateral flow and indirect influence on soil property or evapotranspiration. In this study, the influences of topographic position on soil moisture response and SWS were presented in three aspects, including cumulative rainfall amount and lag time to trigger soil moisture response, soil water flow pattern, and SWS increase.

Firstly, the forest sites in the same position presented the similar soil moisture response features when the rainfall intensity was relative strong, indicating the dominant effects of topography on soil water movement. Also, the time for soil moisture response was earlier in downslope than in upslope for the high intensity characterized rainfall event (Figure 4), implying a lateral water flow from upslope to downslope due to the driving force of topography. These observations were consistent with the study of groundwater response time to rainfall events in a similar steep catchment of Switzerland by Rinderer et al. (2016), who attribute the quicker response of groundwater level to larger water contributing area and subsurface water input at downslope sites. On the contrary, Jin et al. (2018) found downhill gully showed delayed response to rainfall and require a larger amount of rainfall to trigger soil moisture response in Loess Plateau. This difference was partly explained by the vast difference in soil property and initial soil moisture between this study area and Loess Plateau. Silt particles proportion of studied Loess Plateau soils were more than $80 \%$ for the whole soil profile, which was much higher than in this study $(15 \%-40 \%)$. Additionally, a much lower initial soil moisture $(14 \%-15 \%)$ was observed in previous research than in this one $(25 \%-35 \%)$. These differences resulted in more rainfall infiltrated in the deep soil layers and less lateral water flow. Furthermore, much more fine particles and less macropores in the gully led to a much lower infiltration rate than in the upslope site of Loess Plateau.

Secondly, the occurrence of lateral flow along a hillslope is a direct evidence of topographic influence on soil water movement. During the rainfall event of E11, SWS in subsurface layers (i.e. 45, 60, and $80 \mathrm{~cm}$ soil depths, which are close to the low permeable bedrock) presented higher increment than in surface layers, and the increases of SWS at all the profiles were larger than corresponding cumulative rainfall amount. These observations suggested the existence of subsurface lateral flow which was recharged into the soil water in deep soil layers. Except two sites of EG and downslope of SDFS, all other sites detected 
subsurface lateral flow during E11 rainfall event. Subsurface lateral flow was also identified at the lower slope position in several studies (e.g. Kim et al., 2007; Zhu et al., 2014; Guo and Lin, 2018). Moreover, a high increment of soil moisture and SWS were also observed in the upper position of SDFS and DP during the rainfall event of E11, indicating this rainfall event not only triggered subsurface lateral flow at lower slope position but also at upper slope position, especially along the soil-bedrock interface. This result was consistent with the observation of preferential flow occurring widespread even nearly catchment-wide during large storm events (Graham and Lin, 2011; and Wiekenkamp et al., 2016).

Thirdly, lateral water flow resulted in high increase of surface soil moisture and profile SWS at downslope sites (i.e., EG-down and SDFS-down), especially at forest land or during wet period. Lin and Zhou (2008) indicated less permeability subsurface layer and steep slope facilitated lateral flow, which accumulated more input rainwater in the swale and valley position with deeper soil profile. Slope gradient of EG-down and SDFS-down sites were larger than those of upslope sites, and the depths of soil profiles at downslope sites $(80 \mathrm{~cm})$ were larger than that of upslope sites, which explained why the maximum SWS at downslope sites were larger than those of upslope sites, especially during wet period with higher rainfall intensity. This phenomenon was also verified by several researches, which demonstrated that topography dominates distribution of soil moisture regime during wet conditions (Bogena et al., 2010, Yu et al., 2018) and even the variability of groundwater response, especially at steep terrain with shallow groundwater tables (Lana-Renault et al., 2014).

\section{Conclusions}

Three closely located hillslopes covered with EG, SDFS and DP in a hilly catchment were monitored at both upslope and downslope sites to collect soil moisture data at five soil depths from May 1, 2018 to May 1 2019. A total of 55 rainfall events were delineated and soil moisture responding to each event were analyzed with several parameters including cumulative amount and lag time to initiate soil moisture response, wetting depth, and maximum increase of soil moisture and SWS. The results indicate: (1) Rainfall amount was the most prominent rainfall feature for controlling soil moisture response as it had stronger correlation with soil moisture increment than other rainfall features. Average cumulative rainfall amounts for initial moisture response during dry period of all sites were less than those of wet period. During wet period, the cumulative rainfall amount to trigger surface soil response in EG-up site was significantly higher than in other five sites. In contrast, there is no significant differences in cumulative rainfall amounts among six sites during dry period. (2) Vegetation affected the transform ratio of rainfall to soil water by interception and transpiration, showing more rainfall amount and longer lag time was required to initial soil moisture response in vegetation growth period than in fallow period. More water usually infiltrated into forest sites compared with DP, indicated by a higher maximum increment of soil moisture at $10 \mathrm{~cm}$ depth and profile SWS in two forest sites. Topographic feature dominated soil subsurface flow, as less rainfall amount and less time were mostly needed in downslope site to trigger soil moisture increment compared with upslope site in a same slope. (3) Steep slope also leads the downslope sites to collect more rainfall, resulting in more lat- 
eral flow and sudden large increment during heavy rainstorm, which can partly explain the observation of large accumulated SWS in downslope sites compared with corresponding upslope sites during wet period. This study concluded that the integration of the rainfall features, vegetation cover, and topographic position govern the soil moisture response to rainfall events at the hilly area of the Three Gorges Reservoir Area of China.

\section{Acknowledgements}

We appreciate the assistance from the Governors of the Dalaoling Forest Park during the field experiment. Graduate students Lou Shulan, Yang Xiufeng, Li Xiangfu, and Yang Ye are acknowledged for their field work and laboratory measurements.

\section{References}

Albertson J D, Kiely G, 2001. On the structure of soil moisture time series in the context of land surface models. Journal of Hydrology, 243(1/2): 101-119.

Bales R C, Hopmans J W, O'Geen A T et al., 2011. Soil moisture response to snowmelt and rainfall in a Sierra Nevada mixed-conifer forest. Vadose Zone Journal, 10(3): 786-799.

Bogena H R, Herbst M, Huisman J A et al., 2010. Potential of wireless sensor networks for measuring soil water content variability. Vadose Zone Journal, 9(4): 1002-1013.

Brantley S L, Eissenstat D M, Marshall J A et al., 2017. Reviews and syntheses: On the roles trees play in building and plumbing the critical zone. Biogeosciences, 14(22): 5115-5142.

Burt T P, Butcher D P, 1985. Topographic controls of soil moisture distributions. Journal of Soil Science, 36(3): 469-486.

Crockford R H, Richardson D P, 2000. Partitioning of rainfall into throughfall, stemflow and interception: Effect of forest type, ground cover and climate. Hydrological Processes, 14(16/17): 2903-2920.

Famiglietti J S, Rudnicki J W, Rodell M, 1998. Variability in surface moisture content along a hillslope transect: Rattlesnake Hill, Texas. Journal of Hydrology, 210(1-4): 259-281.

Gash J H C, 1979. An analytical model of rainfall interception by forests. Quarterly Journal of the Royal Meteorological Society, 105(443): 43-55.

Graham C B, Lin H S, 2011. Controls and frequency of preferential flow occurrence: A 175-event analysis. Vadose Zone Journal, 10(3): 816-831.

Grayson R B, Western A W, Chiew F H S et al., 1997. Preferred states in spatial soil moisture patterns: Local and nonlocal controls. Water Resources Research, 33(12): 2897-2908.

Guo L, Fan B, Zhang J et al., 2018. Occurrence of subsurface lateral flow in the Shale Hills Catchment indicated by a soil water mass balance method. European Journal of Soil Science, 69(5): 771-786.

Guo L, Lin H, 2018. Addressing two bottlenecks to advance the understanding of preferential flow in soils. Advances in Agronomy, 147: 61-117.

Guzzetti F, Peruccacci S, Rossi M et al., 2008. The rainfall intensity-duration control of shallow landslides and debris flows: An update. Landslides, 5(1): 3-17.

He Z, Zhao W, Liu H et al., 2012. The response of soil moisture to rainfall event size in subalpine grassland and meadows in a semi-arid mountain range: A case study in northwestern China's Qilian Mountains. Journal of Hydrology, 420: 183-190

$\mathrm{Hu}$ W, Si B C, 2014. Revealing the relative influence of soil and topographic properties on soil water content distribution at the watershed scale in two sites. Journal of Hydrology, 516: 107-118.

Iida S, Tanaka T, Sugita M, 2005. Change of interception process due to the succession from Japanese red pine to evergreen oak. Journal of Hydrology, 315(1/4): 154-166.

Jia Y H, Shao M A, 2014. Dynamics of deep soil moisture in response to vegetation restoration on the Loess Pla- 
teau of China. Journal of Hydrology, 519: 523-531.

Kim S, Lee H, Woo N C et al., 2007. Soil moisture monitoring on a steep hillside. Hydrological Processes: An International Journal, 21(21): 2910-2922.

Lana-Renault N, Nadal-Romero E, Serrano-Muela M P et al., 2014. Comparative analysis of the response of various land covers to an exceptional rainfall event in the central Spanish Pyrenees, October 2012. Earth Surface Processes and Landforms, 39(5): 581-592.

Li X Y, Zhang S Y, Peng H Y et al., 2013. Soil water and temperature dynamics in shrub-encroached grasslands and climatic implications: Results from Inner Mongolia steppe ecosystem of north China. Agricultural and Forest Meteorology, 171: 20-30.

Lin H, 2010. Linking principles of soil formation and flow regimes. Journal of Hydrology, 393(1/2): 3-19.

Lin H, Zhou X, 2008. Evidence of subsurface preferential flow using soil hydrologic monitoring in the Shale Hills catchment. European Journal of Soil Science, 59(1): 34-49.

Liu M, Guo L, Yi J et al., 2018. Characterising preferential flow and its interaction with the soil matrix using dye tracing in the Three Gorges Reservoir Area of China. Soil Research, 56(6): 588-600.

McDonnell J J, 2003. Where does water go when it rains? Moving beyond the variable source area concept of rainfall-runoff response. Hydrological Processes, 17(9): 1869-1875.

Rinderer M, van Meerveld I, Stähli M et al., 2016. Is groundwater response timing in a pre-alpine catchment controlled more by topography or by rainfall? Hydrological Processes, 30(7): 1036-1051.

Shao M, Jia X, Wang Y et al., 2016. A review of studies on dried soil layers in the Loess Plateau. Advances in Earth Science, 31(1): 14-22. (in Chinese)

Sidle R C, Tsuboyama Y, Noguchi S et al., 1995. Seasonal hydrologic response at various spatial scales in a small forested catchment, Hitachi Ohta, Japan. Journal of Hydrology, 168(1-4): 227-250.

Tomer M D, Anderson J L, 1995. Variation of soil water storage across a sand plain hillslope. Soil Science Society of America Journal, 59(4): 1091-1100.

Uchida T, McDonnell J J, Asano Y, 2006. Functional intercomparison of hillslopes and small catchments by examining water source, flowpath and mean residence time. Journal of Hydrology, 327(3/4): 627-642.

Wang S, Fu B, Gao G et al., 2013. Responses of soil moisture in different land cover types to rainfall events in a re-vegetation catchment area of the Loess Plateau, China. Catena, 101: 122-128.

Western A W, Grayson R B, Blöschl G et al., 1999. Observed spatial organization of soil moisture and its relation to terrain indices. Water Resources Research, 35(3): 797-810.

Wiekenkamp I, Huisman J A, Bogena H R et al., 2016. Spatial and temporal occurrence of preferential flow in a forested headwater catchment. Journal of Hydrology, 534: 139-149.

Wu J, Huang J, Han X et al., 2003. Three-Gorges Dam-experiment in habitat fragmentation. Science: Ecology, 300: 1239-1240.

Xu Q, Liu S, Wan X et al., 2012. Effects of rainfall on soil moisture and water movement in a subalpine dark coniferous forest in southwestern China. Hydrological Processes, 26(25): 3800-3809.

Yin Y, Wang H, Gao Y et al., 2010. Real-time monitoring and early warning of landslides at relocated Wushan Town, the Three Gorges Reservoir, China. Landslides, 7(3): 339-349.

Yu B, Liu G, Liu Q et al., 2018. Soil moisture variations at different topographic domains and land use types in the semi-arid Loess Plateau, China. Catena, 165: 125-132.

Zhu Q, Nie X, Zhou X et al., 2014. Soil moisture response to rainfall at different topographic positions along a mixed land-use hillslope. Catena, 119: 61-70. 